\title{
List of Papers not Included in the Present Collection
}

- 'Hesiod's style: towards an ancient analysis', in: F. Montanari/A. Rengakos/C. Tsagalis (eds.), Brill's Companion to Hesiod (Leiden 2009) 253-269.

- $\quad$ 'Greek elegy', in: T.S. Thorsen (ed.), The Cambridge Companion to Latin Love Elegy (Cambridge 2013) 23-38.

- 'Callimachus and Roman Elegy', in: B. Gold (ed.), A Companion to Roman Love Elegy (Malden MA 2012) 155-171.

- $\quad$ (with D. Koukouzika), 'Food in Greek literature', in: J. Wilkins/R. Nadeau (eds.), A Companion to Food in the Ancient World (Malden MA 2015) 19-29.

- 'Poetic Unity, Greek', in: S. Goldberg (ed.), The Oxford Classical Dictionary Online (New York).

- 'The idea of the classical in classical antiquity', Proceedings of the Academy of Athens 90 (2015) 51-68.

- 'Hesiodic studies: a cross-cultural endnote', Seminari Romani di Cultura Greca 5 (2016) 223-226.

- $\quad$ 'A striking parallel?', in: K. Coleman (ed.), Albert's Anthology (Cambridge MA 2017) 91-92.

- 'esse quam uideri', in: N. Hatton/S. Hobe/V. Mastellari (eds.), Hacks, Quacks and Impostors (Freiburg 2019) 17-35.

- 'Afterword', in: A.-E. Beron/S. Weise (eds.), Hyblaea avena. Theokrit in römischer Kaiserzeit und früher Neuzeit (Stuttgart 2020) 197-200.

- 'Memory and its discontents in ancient literature', in: K. Mawford/E. Ntanou (eds.), Ancient Memory. Remembrance and Commemoration in Graeco-Roman Literature (Berlin 2021) 293-308.

Also omitted are Introductions to edited volumes, in all cases co-written with another editor. 
